\title{
ANALISIS KRITIS PROGRAM PENGELOLAAN DANA ZAKAT DAN INFAK DALAM MEMBENTUK MODAL SOSIAL MASYARAKAT 1$]$
}

\author{
Nairatul Ahkamiyah \\ Mahasiswa Program Studi S1 Ekonomi Islam-Fakultas Ekonomi dan Bisnis-Universitas Airlangga \\ Email :nairatul.ahkamiyah-13@feb.unair.ac.id
}

Suherman Rosyidi

Departemen Ekonomi Syariah-Fakultas Ekonomi dan Bisnis-Universitas Airlangga

Email : suherman.rosyidi@feb.unair.ac.id.

\begin{abstract}
The existence of religious institutions has a positive relationship with the strengthening of social capital and improving the welfare of poor community. The religious institution that is the subject of this research is the Tebuireng Pesantren Social Institution (LSPT). This research aims to analyze the management program of zakat funds and infak by LSPT in shaping social capital of the surrounding communities. The research method used in this research is descriptive qualitative.Through the PMM program and the griya dakwah program, LSPT forms social capital. The PMM program has been able to shape the social capital of the poor community, but has not been fully successful. Main job Griya dakwah program is to launch someone who is an expert in related field to preach in Ngimbang community. The main activity of the griya dakwah program is routine study every friday night, the study further strengthens social capital in the Ngimbang community.
\end{abstract}

Keywords: Social capital, LSPT, Zakat, Infak.

\section{PENDAHULUAN}

Islam merupakan agama yang kaffah atau sempurna. Islam mengatur segala aspek urusan kehidupan manusia baik yang berhubungan dengan ibadah ataupun muamalah. Salah satu perintah Allah yang masuk dalam kategori ibadah dan memiliki dampak terhadap hubungan manusia (muamalah) adalah perintah menunaikan zakat.

Zakat merupakan kewajiban bagi setiap muslim yang mampu menunaikannya, serta menjadi bagian dalam rukun Islam. Infak merupakan wujud kecintaan hamba terhadap nikmat dari Allah SWT yang telah diberikan kepadanya sehingga seorang hamba rela menyisihkan sebagian hartanya untuk kepentingan agama, baik dalam rangka membantu sesama maupun perjuangan dakwah Islamiyah. Allah SWT berfirman dalam surah Al-Baqarah ayat 195:

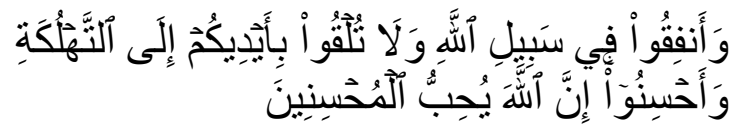

Wa-anfiqū fī sabili 'I-Lāhi walā tulqū biaidīkum ilā 't-tahlukati wa-ahsinū inna 'ILāha yuhibbu 'I-muhsinīna

Artinya: "Dan belanjakanlah (harta bendamu) di jalan Allah, dan janganlah kamu menjatuhkan dirimu sendiri ke dalam kebinasaan, dan berbuat baiklah, karena sesungguhnya Allah menyukai orang-orang yang berbuat baik". (QiW)

$$
\text { Indonesia merupakan negara }
$$

dengan kondisi perekonomian penduduk yang masih kebanyakan berpenghasilan rendah. Menurut Badan Pusat Statistik (BPS) menginformasikan jumlah penduduk miskin (penduduk dengan pengeluaran per kapita 
Ahkamiyah, et al/Jurnal Ekonomi Syariah Teori dan Terapan Vol. 5 No.7 Juli 2018: 590-603; ANALISIS KRITIS PROGRAM PENGELOLAAN DANA ZAKAT DAN INFAK DALAM MEMBENTUK MODAL SOSIAL MASYARAKAT

di bawah garis kemiskinan) di Indonesia per September 2016 mencapai 27,76 juta orang (Setkab.go.id).

Ummat Islam di Indonesia tentunya tidak dapat dikecualikan dalam fenomenafenomena kemiskinan di Indonesia. Apalagi Indonesia merupakan negara dengan penduduk Muslim terbanyak di dunia, tentunya potensi penerimaan dana zakat dan infak (secara bersama-sama keduanya disebut ZIS) memiliki potensi yang besar. Badan Amil Zakat Nasional (BAZNAS) menyebutkan dalam website resminya, bahwa potensi penerimaan ZIS di Indonesia tahun 2016 mencapai Rp 217 triliun. Potensi tersebut seharusnya ZIS mampu membantu pemerintah dalam menanggulangi kemiskinan di negeri ini. Hamim (2016:4) menjelaskan bahwa Potensi ini merupakan sumber pendanaan yang dapat dijadikan kekuatan pemberdayaan ekonomi, pemerataan pendapatan, bahkan akan dapat menggerakkan roda perekonomian negara.

Untuk menggerakkan perekonomian negara tentunya akan menyangkut aktifitas ekonomi masing-masing individu yang ada di dalam negara tersebut. Para ahli ekonomi berpendapat bahwa menggerakkan aktifitas ekonomi tidak cukup dengan hanya mengandalkan modal manusia, modal budaya, modal keuangan maupun modal fisik saja. Ada modal lain yang lebih efektif dan dapat melengkapi modal-modal tersebut dalam meningkatkan aktifitas ekonomi masyarakat yaitu modal sosial. Widayani dan Nisa (2013:66) mengatakan bahwa modal sosial merupakan modal atau sumber daya yang berupa hubungan antar masyarakat yang mampu membentuk suatu jaringan dan mendorong untuk saling bekerja-sama dalam jangka waktu yang cukup lama serta dapat menumbuhkan rasa kepercayaan yang dilandaskan pada norma-norma yang telah disetujui guna untuk mencapai tujuan bersama.

Berdasarkan fakta-fakta di atas, menarik untuk dilakukan penelitian tentang bagaimana program pengelolaan dana zakat dan infak dalam membentuk modal sosial masyarakat sekitar yang berada di kawasan Pondok Pesantren Tebuireng. Pemilihan Lembaga Sosial Pesantren Tebuireng (selanjutnya disingkat LSPT) sebagai subjek penelitian dikarenakan lembaga ini memiliki daya tarik tersendiri bagi masyarakat luas. Selain karena lembaga ini didirikan di dalam lingkungan pesantren yang cukup terkenal di Indonesia yaitu pesantren Tebuireng, lembaga ini juga merupakan lembaga pengumpul zakat yang diawasi langsung oleh pesantren dengan sistem administrasi yang cukup baik.

Berdasarkan paparan latar belakang di atas maka rumusan masalah dalam penelitian ini adalah : Bagaimana program pengelolaan dana zakat dan infak Lembaga Sosial Pesantren Tebuireng dalam membentuk modal sosial masyarakat sekitarnya?

Adapun tujuan yang ingin dicapai dalam penelitian ini adalah untuk menganalisis program pengelolaan dana zakat dan infak Lembaga Sosial Pesantren 
Ahkamiyah, et al/Jurnal Ekonomi Syariah Teori dan Terapan Vol. 5 No.7 Juli 2018: 590-603;

ANALISIS KRITIS PROGRAM PENGELOLAAN DANA ZAKAT DAN INFAK DALAM MEMBENTUK MODAL SOSIAL MASYARAKAT

Tebuireng dalam membentuk modal sosial masyarakat

sekitarnya.

\section{LANDASAN TEORI}

Al Ghaziy (2005:22) menjelaskan menjelaskan arti zakat

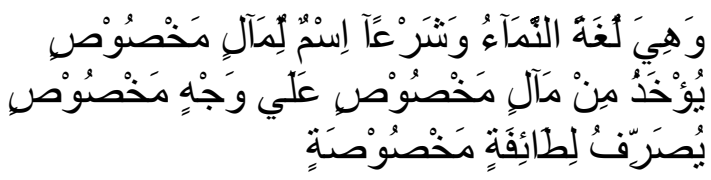

Wahiya lughatan a 'n-namā'u wasyar'ān ismun limālin makhșūșin yu'khażu min mālin makhșūșin 'alā wajhin makhșūșin yușarrifu lițā-ifatin makhșūșatin

Artinya: Adapun ia (zakat) secara bahasa berarti berkembang, sedangkan menurut syara' atau istilah zakat nama harta yang tertentu, yang diambil dari harta tertentu dengan cara tertentu dan juga dipergunakan untuk golongan tertentu.

Zakat berarti berkembang atau tumbuh. Hal itu karena orang yang mengeluarkan sebagian hartanya maka harta orang tersebut akan tumbuh dan berkembang.

Infak berasal dari kata anfaqa yang berarti mengeluarkan sesuatu (harta) untuk kepentingan tertentu. Hafidhuddin (2008:15) menyatakan bahwa "...menurut terminologi syariat, infak berarti mengeluarkan sebagian harta atau pendapatan/penghasilan untuk suatu kepentingan yang diperintahkan ajaran Islam".

Secara spesifik dalam pengelolaan dana ZIS, hanya diperuntukkan untuk memenuhi kebutuhan hidup para mustahiq (konsumtif), tetapi jika dana ZIS tersebut telah mampu memenuhi kebutuhan hidup mustahiq maka akan

lebih baik apabila dana ZIS juga dialokasikan untuk usaha produktif yang dapat membuat kehidupan para mustahiq lebih baik.

Selanjutnya adalah modal sosial.. Definisi modal sosial menurut Putnam dalam jurnal Kearns (2004:7):

"features of social life networks, norms and trust - that enable participants to act together more effectively to pursue shared objectives...Social capital, in short, refers to social connections and the attendant norms and trust" (Putnam 1995)

secara garis besar modal sosial mencakup tiga unsur penting yaitu jaringan (network), kepercayaan (trust), dan norma-norma (norms). Sanrego dan Taufik (2016:138) menyebutkan bahwa disamping tiga elemen tersebut terdapat satu elemen yang juga tidak kalah penting yaitu timbal balik (reciprocity).

Islam telah terlebih dahulu mengajarkan tentang konsep modal sosial melalui konsep ukhuwah (persaudaraan) dalam bingkai kesatuan akidah dan keimanan." Konsep atas dasar keimanan atau sering disebut ukhuwah islamiyah ini merupakan dasar terciptanya modal sosial. Allah SWT dalam surah Al-Hujurat ayat 10

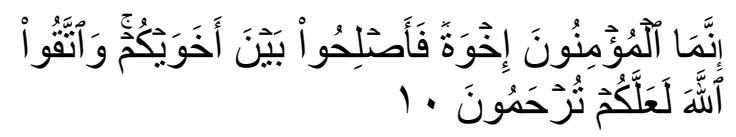

Innamā 'I-mu'minūna ikhwatun faașlihū bayna akhawaykum wa 't-taqū 'ILāha la'allakum turhamūna 
Ahkamiyah, et al/Jurnal Ekonomi Syariah Teori dan Terapan Vol. 5 No.7 Juli 2018: 590-603; ANALISIS KRITIS PROGRAM PENGELOLAAN DANA ZAKAT DAN INFAK DALAM MEMBENTUK MODAL SOSIAL MASYARAKAT

Artinya: "Orang-orang beriman itu sesungguhnya bersaudara. Sebab itu damaikanlah (perbaikilah hubungan) antara kedua saudaramu itu dan takutlah terhadap Allah, supaya kamu mendapat rahmat." (QiW)

Sanrego dan Taufik (2016:133) membagi surah Al-Hujurat ayat 10 menjadi tiga bagian yaitu:

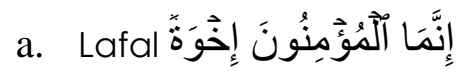

Lafal ini mengandung pondasi awal bagi terwujudnya sebuah modal sosial (social capital). Modal sosial dapat terbangun dengan kokoh dalam nilai-nilai yang terkandung dalam ayat tersebut yakni nilai ukhuwah (persaudaraan).

\section{Proposisi}

Secara spesifik dalam pengelolaan dana ZIS, hanya diperuntukkan untuk memenuhi kebutuhan hidup para mustahia (konsumtif), tetapi jika dana ZIS tersebut telah mampu memenuhi kebutuhan hidup mustahiq maka akan lebih baik apabila dana ZIS juga dialokasikan untuk usaha produktif yang dapat membuat kehidupan para mustahiq lebih baik, terutama dalam aspek ekonomi. Hal ini tidak mudah untuk dilakukan tanpa adanya penggerak dari dalam diri mustahiq itu sendiri, oleh karena itu pembentukan modal sosial dalam

\section{METODE PENELITIAN}

\section{Pendekatan Penelitian}

Penelitian ini menggunakan pendekatan kualitatif deskriptif, Sugiyono (2013:1) menjelaskan tentang penelitian kualitatif bahwa "...peneliti merupakan b. Lafal

Lafal kedua ini merupakan metode manajemen konflik guna memelihara keutuhan modal sosial yang telah terbangun.

$$
\text { c. Lafal Lَعَلَّكُمُ ثُرْحَمُونَ }
$$

Lafal ketiga merupakan sebuah hasil yang akan diperoleh dari terpeliharanya modal sosial yang terdapat di masyarakat, yakni berupa rahmat dari Allah SWT.

penyaluran dana ZIS dianggap mampu menggerakkan masyarakat terutama golongan ekonomi lemah untuk memperbaiki kehidupannya baik dalam bidang ekonomi ataupun sosial.

Proposisi penelitian digunakan sebagai batasan untuk menampilkan suatu penyempitan data yang relevan. Di sini disampaikan batasan bagi ruang lingkup penelitian ini sebagai objek penelitian yakni upaya pengelolaan dana ZIS oleh lembaga pengumpul zakat dalam membentuk modal sosial untuk mewujudkan kesejahteraan (falah) bagi mustahiq.

instrumen kunci, teknik pengumpulan data dilakukan secara triangulasi (gabungan), analisis data bersifat induktif dan hasil penelitian kualitatif lebih menekankan makna dari pada generalisasi." 
Ahkamiyah, et al/Jurnal Ekonomi Syariah Teori dan Terapan Vol. 5 No.7 Juli 2018: 590-603; ANALISIS KRITIS PROGRAM PENGELOLAAN DANA ZAKAT DAN INFAK DALAM MEMBENTUK MODAL SOSIAL MASYARAKAT

\section{Ruang Lingkup Penelitian}

Penelitian ini dilakukan untuk menjawab rumusan masalah pada penelitian ini yaitu "Bagaimana model pengelolaan dana zakat dan infak LSPT dalam membentuk modal sosial masyarakat sekitar?".

Rumusan masalah tersebut menjadi acuan sebagai pembatasan ruang lingkup penelitian.Ruang lingkup pada rumusan masalah di atas adalah bagaimana program-program pengelolaan dan penyaluran dana zakat dan infak di LSPT dapat membentuk modal sosial pada masyarakat sekitar pesantren tersebut.

\section{Jenis dan Sumber Data}

Jenis data yang digunakan dalam penelitian ini berupa data primer dan data sekunder. Data primer merupakan data utama yang diperoleh peneliti dari lapangan secara langsung. Data primer terutama berasal dari wawancara dengan pengurus LSPT dan dokumendokumen yang berhubungan dengan model pengelolaan dana zakat dan infak di lembaga tersebut. Data sekunder berupa data tambahan yang didapatkan peneliti dari pihak selain LSPT, misalnya internet, jurnal, tulisan makalah seminar, buku, majalah serta sumber lain yang berkaitan dengan penelitian ini.

\section{Teknik Analisis Data}

Teknik analisis yang digunakan dalam penelitian ini adalah teknik analisis menurut Miles and Huberman sebagimana yang disebut oleh Sugiono
(2013:102) yang menjelaskan ada tiga proses yaitu; data reduction (reduksi data), data display (penyajian data) dan conclusion drawing/verification (menarik kesimpulan/verifikasi).

1. Data reduction (Reduksi Data)

Data yang diperoleh saat wawancara pada umumnya cukup banyak dan sangat luas, untuk itu perlu dipersempit untuk memudahkan peneliti dalam memilah data tersebut. Melakukan reduksi data berarti merangkum, memilih hal-hal yang sangat pokok, dan memfokuskan pada hal-hal yang sangat penting.

2. Data display (Penyajian Data)

Setelah data direduksi, maka langkah selanjutnya adalah menyajikan data. Dalam penelitian kualitatif, penyajian data dapat dilakukan dalam bentuk uraian singkat, bagan, flowchart dan sejenisnya. Tetapi dalam penelitian kualitatif lebih sering digunakan teks naratif.

3. Conclusion drawing/Verification (Menarik Kesimpulan/Verifikasi)

Langkah ketiga dalam teknik analisis data adalah penarikan kesimpulan. Kesimpulan awal yang dikemukakan masih bersifat sementara, dan akan berubah apabila tidak didukung oleh bukti-bukti yang valid. Tetapi apabila kesimpulan pada tahap awal didukung oleh kesimpulan yang disertai dengan bukti-bukti valid maka kesimpulan yang dikemukakan merupakan kesimpulan yang kredibel. 
Ahkamiyah, et al/Jurnal Ekonomi Syariah Teori dan Terapan Vol. 5 No.7 Juli 2018: 590-603; ANALISIS KRITIS PROGRAM PENGELOLAAN DANA ZAKAT DAN INFAK DALAM MEMBENTUK MODAL SOSIAL MASYARAKAT

\section{Hasil dan Pembahasan}

LSPT yang didirikan pada tahun 2007 merupakan lembaga non-profit yang mengelola zakat, infak, sedekah, wakaf tunai atau dana sosial lainnya. Dana tersebut berasal dari para alumni, donatur dan kotak infak yang berada di sekitar pesantren. Dengan dibentuknya LSPT, diharapkan dana zakat, infak, sedekah dan lainnya dapat dikelola secara profesional dalam menanggulangi masalah kemiskinan baik penghuni pesantren ataupun masyarakat sekitar.

Berdirinya LSPT ini mendapat sambutan yang sangat baik dari semua pihak, yaitu donatur, santri, orangtua santri, alumni dan sebagainya. Kemudian Pada tahun 2013, LSPT resmi menjadi UPZ melalui surat keputusan nomor 88/SKUPZ/BAZ.PR/2013 yang dikeluarkan oleh BAZNAS Propinsi Jawa Timur.

LSPT sebagai UPZ memiliki beberapa program unggulan dalam penyaluran dana zakat, infak maupun dana sosial yang lain. Program-program tersebut meliputi:

\section{1). Pendidikan}

Bidang pendidikan difokuskan untuk meningkatkan kualitas pendidikan dan menekan angka putus sekolah, LSPT memberikan bantuan biaya pendidikan pada kaun dhuafa. Selain bantuan biaya pendidikan, LSPT juga memberikan beasiswa terhadap anak-anak yang berprestasi baik akademik maupun non akademik.

2). Peduli Yatim Piatu
Program ini bertujuan memberikan biaya untuk mendukung pendidikan anakanak yatim dhuafa jenjang SD, SMP, hingga SMA. Selain bantuan biaya pendidikan bagi anak yatim piatu, LSPT juga memberikan bantuan kepada Panti Asuhan.

3). Kesehatan

Bidang kesehatan, LSPT memiliki program Kartu Tebuireng Sehat (KTS). Warga yang memiliki KTS ini dapat berobat secara gratis ke Pusat Kesehatan Pesantren Tebuireng (PUSKESTREN). Selain KTS, untuk meningkatkan kesehatan khususnya pada kaum dhuafa LSPT juga memberikan layanan pengobatan gratis.

4). Kemanusiaan

Sebagai wujud nyata kepedulian kita terhadap kaum dhuafa yang membutuhkan bantuan atau pertolongan. LSPT memiliki Tim Respon Cepat (TRC), tim ini siap berkiprah melaksanakan dan membantu untuk mengurangi derita sesama akibat bencana alam maupun tragedi sosial lainnya.

5). Dakwah

Program yang lebih sering disebut griya dakwah ini diwujudkan dengan pemberian bantuan oleh LSPT untuk kegiatan dakwah dan operasional lembaga dakwah. LSPT mengutus salah satu ustadz dari pesantren untuk berdakwah ke suatu daerah yang pemahaman tentang agama Islam masih sangat minim. Daerah sasaran dakwah tersebut yaitu desa terpencil yang berada 
Ahkamiyah, et al/Jurnal Ekonomi Syariah Teori dan Terapan Vol. 5 No.7 Juli 2018: 590-603; ANALISIS KRITIS PROGRAM PENGELOLAAN DANA ZAKAT DAN INFAK DALAM MEMBENTUK MODAL SOSIAL MASYARAKAT

di Kabupaten Mojokerto dan Kabupaten Lamongan.

6). Peduli TPQ

Program pelatihan guru TPA/TPQ dan program penghafal surat-surat pendek TPQ binaan.

7). Wakaf Al-Qur'an dan Pembinaan

Program pendistribusian Al-Qur'an wakaf terpadu ke daerah-daerah rawan aqidah dan rawan pendidikan. Setelah daerah sasaran ditentukan, LSPT kemudian mengirimkan tim untuk mendalami berbagai informasi daerah dan keadaan masyarakat, serta membangun komunikasi dengan dai atau mubaligh di daerah rawan aqidah dan pendidikan tersebut. Di beberapa daerah, program ini dipadukan dengan Tabligh Akbar yang biasanya diisi oleh mubaligh nasional, dan mengundang para tokoh setempat serta dihadiri warga.

8). Bantuan Masjid/Musholla

Bantuan ini berupa rehabilitasi fasilitas Masjid dan Musholla.

9). Bantuan Masyarakat Miskin

Program ini lebih dikenal dengan Peduli Masyarakat Miskin (untuk seterusnya disingkat PMM). Sebelum mendapatkan bantuan, LSPT akan menyeleksi dan melakukan survey terhadapa orang-orang yang dianggap tidak mampu secara ekonomi. Hal ini dilakukan agar bantuan atau donasi yang diberikan tepat sasaran. Program ini juga bertujuan merangsang para dhuafa untuk memiliki usaha mandiri yang dapat dijadikan sumber penghasilan.
Keberadaan lembaga keagamaan memiliki hubungan positif dengan penguatan modal sosial masyarakat dan peningkatan kesejahteraan masyarakat miskin. Modal sosial adalah modal atau sumber daya yang berupa hubungan antar masyarakat yang mampu membentuk suatu jaringan dan mendorong untuk saling bekerja-sama dalam jangka waktu yang cukup lama serta dapat menumbuhkan rasa kepercayaan yang dilandaskan pada norma-norma yang telah disetujui guna untuk mencapai tujuan bersama. Terdapat empat indikator untuk mengukur terbentuknya modal sosial, dengan melihat ada atau tidaknya elemenelemen modal sosial dalam suatu masyarakat atau perkumpulan tertentu. Menurut Putnam dalam Sanrego dan Taufik (2016:129) elemen-elemen tersebut meliputi norma (norms), jaringan (network), timbal balik (reciprocity) dan kepercayaan (trust).

\section{Norma (Norms)}

Norma merupakan sekumpulan aturan yang diharapkan dapat dipatuhi dan dijalankan oleh anggota masyarakat pada suatu entitas tertentu. Suharto (2008:4) menjelaskan bahwa "Normanorma dapat bersumber dari agama, panduan moral, maupun standar-standar sekuler seperti halnya kode etik profesional." Secara implisit, ajaran agama Islam sudah terkandung dalam elemen modal sosial yang pertama ini. 
Ahkamiyah, et al/Jurnal Ekonomi Syariah Teori dan Terapan Vol. 5 No.7 Juli 2018: 590-603; ANALISIS KRITIS PROGRAM PENGELOLAAN DANA ZAKAT DAN INFAK DALAM MEMBENTUK MODAL SOSIAL MASYARAKAT

$\begin{array}{ccr} & \text { Program-program LSPT } & \text { sebagian } \\ \text { besar } & \text { selalu difokuskan } & \text { untuk }\end{array}$ mengajarkan dan mengamalkan nilai-nilai ajaran Islam. Program PMM misalnya; program ini dikemas dengan kajian rutin setiap bulannya dengan mendatangkan pemateri atau ustadz yang sudah dikader terlebih dahulu di dalam Pesantren Tebuireng. Program Dakwah dan program pendidikan juga mendapat perhatian yang cukup besar dari pengurus LSPT. Program-program ini juga dimanfaatkan untuk menyebarkan nila-nilai kepesantrenan yaitu ajaran Islam kepada masyarakat luas khususnya mustahiq LSPT, bahkan dua program ini merupakan program yang paling banyak menyerap penyaluran dana infak selama tahun 2016.

Hasil wawancara menunjukkan bahwa tujuan utama dari programprogram LSPT adalah untuk membantu masyarakat dalam segi ekonomi dan pemahaman spiritual. Hal ini disampaikan oleh pengurus LSPT "Jadi yang diharapkan mungkin lebih ke kualitas hidup baik kesehatan dan agama, terutama."

Pemilihan strategi dakwah yang dijalankan LSPT membawa dua manfaat sekaligus yaitu masyarakat terbantu secara materi dan juga menambah wawasan agama mereka. Hal ini sesuai dengan perintah Rasulullah kepada ummat Islam untuk selalu mengingatkan satu sama lain dalam hal kebaikan dan berbagi ilmu pengetahuan, meskipun hanya sedikit. Rasulullah bersabda

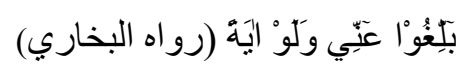

Balligū 'annī wa-law āyatan (rawāhu 'I-Bukhārì)

Artinya: "Sampaikanlah dariku walau hanya satu ayat" (H.R. Bukhari)

\section{Jaringan (Network)}

Mawardi dalam Sanrego dan Taufik (2016:139) menjelaskan bahwa

Modal sosial akan dapat terbangun dengan baik ketika tumbuh sebuah kecenderungan dalam sebuah kelompok untuk saling bersosialisasi satu dengan yang lainnya. Besar kecilnya modal sosial dalam sebuah masyarakat, sangat tergantung pada kapasitas yang ada dalam kelompok masyarakat untuk membangun sejumlah asosiasi berikut membangun jaringannya.

Kecenderungan sebuah kelompok untuk saling bersosialisasi dapat dengan mudah terbentuk karena adanya rasa kesamaan diantara kelompok itu sendiri, baik kesamaan demografis, suku, agama, profesi ataupun nasib. Hal inilah yang juga menjadi awal pembentukan modal sosial pada mustahia LSPT yang menerima bantuan melalui PMM. Intensitas bertemu dan berinteraksi yang sudah diagendakan setiap bulannya oleh LSPT serta rasa kesamaan nasib yaitu sama-sama bagian dari peserta pengajian menjadikan mustahiq yang awalnya tidak kenal akhirnya dapat saling mengenal. Bahkan perkenalan tersebut juga membuat para mustahiq sering bersilaturrahim di luar acara tersebut, meskipun tidak formal. Sikap saling mengenal dan saling 
Ahkamiyah, et al/Jurnal Ekonomi Syariah Teori dan Terapan Vol. 5 No.7 Juli 2018: 590-603; ANALISIS KRITIS PROGRAM PENGELOLAAN DANA ZAKAT DAN INFAK DALAM MEMBENTUK MODAL SOSIAL MASYARAKAT

silaturrahim ini jika terus menerus, suatu saat akan berubah menjadi suatu kerjasama yang dapat menguntungkan satu sama lain.

Islam tidak hanya mengajarkan untuk beribadah kepada Allah, akan tetapi sebagai makhluk sosial manusia juga diperintahkan untuk saling mengenal, berinteraksi dan menjalin hubungan yang baik. Perintah ini tidak hanya berlaku untuk sesama ummat Islam, tapi juga berlaku untuk seluruh ummat manusia. Allah berfirman dalam surah Al Hujurat ayat 13:

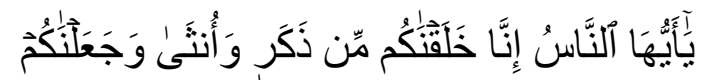

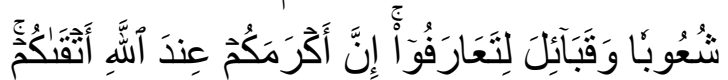

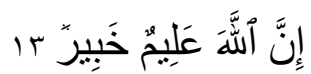

Yā-ayyuha 'n-nāsu innā khalaqnākum min żakarin wa-unśā waja'alnākum syu'ūbān waqabā-ila lita'arafū inna akramakum 'inda 'I-Lahi atqākum inna 'I-Laha 'alimun khabīrun

Artinya: " Hai manusia, sesungguhnya Kami menciptakan kamu dari seorang laki-laki dan seorang perempuan dan menjadikan kamu berbangsa-bangsa dan bersuku-suku supaya kamu saling kenal-mengenal. Sesungguhnya orang yang paling mulia diantara kamu disisi Allah ialah orang yang paling takwa diantara kamu. Sesungguhnya Allah Maha Mengetahui lagi Maha Mengenal." (QiW)

Shihab (2002:618) menjelaskan bahwa ayat di atas menekankan pentingnya saling mengenal. "Perkenalan itu dibutuhkan untuk saling menarik pelajaran dan pengalaman pihak lain guna meningkatkan ketakwaan kepada Allah SWT. yang dampaknya tercermin pada kedamaian dan kesejahteraan hidup duniawi dan kebahagiaan ukhrawi." Mengenal saja tidak cukup, perlu adanya tindak lanjut yaitu dengan silaturrahim. Silaturrahim dapat menimbulkan rasa saling menghargai dan menyayangi diantara suatu kelompok masyarakat, sehingga rasa saling menghargai dan menyayangi inilah yang mampu memperkokoh suatu jaringan.

Rasa saling menghargai dan menyayangi inilah yang tergambar dalam setiap acara kajian rutin program PMM setiap bulannya dan acara kajian rutin setiap minggunya di desa Ngembang, yang merupakan desa sasaran dakwah LSPT.

\section{Timbal Balik (Reciprocity)}

Reciprocity adalah hubungan timbal balik dan saling menguntungkan. Kecenderungan untuk saling tukar kebaikan atau membalas kebaikan antar individu dalam suatu kelompok merupakan suatu fitrah manusia. Mawardi dalam Sanrego dan Taufik (2016:142) mengatakan bahwa "Dalam masyarakat yang memiliki modal sosial tinggi, reciprocity akan terefleksikan dalam bentuk kepedulian sosial yang tinggi, saling membantu dan saling memperhatikan." Semakin tinggi tingkat kepedulian antar individu dalam suatu 
Ahkamiyah, et al/Jurnal Ekonomi Syariah Teori dan Terapan Vol. 5 No.7 Juli 2018: 590-603; ANALISIS KRITIS PROGRAM PENGELOLAAN DANA ZAKAT DAN INFAK DALAM MEMBENTUK MODAL SOSIAL MASYARAKAT

daerah maka semakin tinggi pula modal sosial yang dimiliki oleh daerah tersebut.

Konsep ukhuwah yang diajarkan dalam agama Islam mewajibkan pemeluknya untuk saling mengasihi, saling tolong-menolong dan saling berbagi kebaikan. Rasulullah bersada

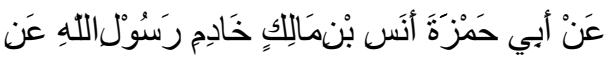

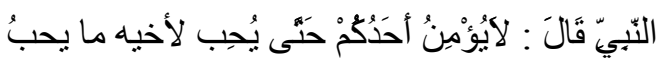

$$
\begin{aligned}
& \text { لِنَفْسِِهِ (رو اه البخاري ومسلم) }
\end{aligned}
$$

'an abī hamzata anasi'bni mālikin khādimun rasuli 'l- Lahi 'ani 'n-nabiyyi qāla lā yu'minu ahadukum hattā yuhibbu linafsihì mina'I-Khayri (rawāhu 'I-Bukharī wa-muslim)

Artinya: Dari Abu Hamzah, Anas bin Malik Radhiyallahu 'anhu, dari Nabi Shallallahu 'alaihi wasallam, beliau bersabda: "Tidak sempurna iman seseorang diantara kalian hingga ia mencintai untuk saudaranya apa yang ia cintai untuk dirinya sendiri (H.R. Bukhari dan Muslim)

Pada hadits di atas, Rasulullah menyatakan tidak sempurna iman seorang muslim sampai dia mencintai saudaranya sebagaimana dia mencintai dirinya sendiri. Mencintai dalam hal ini yakni berbagi kebaikan dalam segala hal, baik materi maupun non materi. Jika kecintaan terhadap orang lain sebesar mencintai diri sendiri, gotong royong dan saling membantu satu sama lain, maka tujuan Islam untuk mencapai falah dapat terealisasi dengan baik.

Reciprocity belum sepenuhnya tergambar pada mustahiq-mustahiq yang menerima bantuan dari LSPT. Meskipun LSPT telah memberikan wadah bagi para mustahiq untuk membangun rasa gotong royong atau saling tukar kebaikan, nyatanya hal itu belum mampu menciptakan hubungan timbal balik tersebut. Hasil wawancara menunjukkan bahwa sebenarnya para mustahiq sudah mempunyai keinginan untuk membalas kebaikan para donatur dan pengurus LSPT, akan tetapi hal ini terhalang oleh ketidakberdayaan mereka sebagai golongan orang yang lemah. Hal menarik yang ditemukan ketika penelitian adalah bahwasanya reciprocity ini malah dimiliki oleh masyarakat sekitar Tebuireng yang berbondong-bondong ingin menjadi donatur di LSPT. Bapak Dawam, salah satu donatur LSPT mengatakan bahwa

Kalau dulu anggota donatur hanya sekian kalau sekarang saya lihat sudah sampai berapa ribu itu. Mungkin mereka tertarik dengan program-programnya. Bahkan terkadang satu rumah ada tujuh orang, itu semua menjadi anggota donatur, seluruh keluarga, itu ada di Bulurejo seperti itu. Mungkin juga karena ada nama Tebuireng di LSPT jadi mereka tertarik.

\section{Percaya (Trust)}

Kepercayaan sangat penting adanya di dalam menjalin hubungan baik bermasyarakat ataupun berbisnis. Manusia dapat bekerjasama karena adanya rasa percaya satu sama lain untuk dapat saling menguntungkan. Dalam konteks modal sosial, Piotr 
Ahkamiyah, et al/Jurnal Ekonomi Syariah Teori dan Terapan Vol. 5 No.7 Juli 2018: 590-603; ANALISIS KRITIS PROGRAM PENGELOLAAN DANA ZAKAT DAN INFAK DALAM MEMBENTUK MODAL SOSIAL MASYARAKAT

Sztompka dalam Sanrego dan Taufik (2016:145) menyatakan bahwa percaya adalah "...sebuah bentuk keinginan untuk mengambil resiko dalam hubunganhubungan sosialnya; yang itu didasari oleh perasaan percaya dan yakin bahwa yang lain akan melakukan sesuatu seperti yang diharapkan dan akan senantiasa bertindak dalam suatu pola tindakan yang saling menguntungkan."

Percaya dalam bahasa arab berasal dari kata amana yang berarti kepercayaan, lurus, jujur, setia, aman, sentosa. Jika dikaji lebih dalam, makna kata amanah sangatlah luas. Memberikan masukan kepada orang yang meminta pendapat termasuk amanah, memyampaikan pesan juga termasuk amanah. Jadi amanah mencakup segala sifat mulia yang dapat membuat orang lain percaya kepada kita. Amanah juga merupakan salah satu sifat yang dimiliki Rasul dan sudah sepatutnya dimiliki pula oleh setiap manusia. Allah berfirman dalam surah Al-mu'minun ayat 8

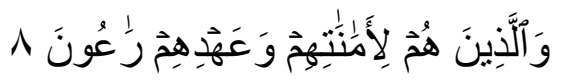

Wa 'I-lażīnahum li-amānātihim wa'ahdihim rā'ūna

Artinya: "Dan orang-orang yang memelihara amanat-amanat (yang dipikulnya) dan janjinya." (QiW)

Mengenai ayat di atas, Shihab (2002:328) menjelaskan bahwa

Islam mengajarkan bahwa amanat/kepercayaan adalah asas keimanan berdasar sabda Nabi saw.: "Tidak ada iman bagi yang tidak memiliki amanah". Selanjutnya, amanah yang merupakan lawan dari khianat adalah sendi utama interaksi. Amanah tersebut membutuhkan kepercayaan dan kepercayaan itu melahirkan ketenangan batin yang selanjutnya melahirkan keyakinan dan kepercayaan.

Dalam hubungannya dengan persoalan amanah inilah semua dana ZIS yang diterima LSPT dikelola dan disalurkan dengan penuh amanah melalui programprogram yang sudah disebutkan sebelumnya. Hal ini menyebabkan kepercayaan dari masyarakat Tebuireng dan sekitarnya menjadi meningkat sehingga jumlah donaturpun ikut meningkat. Dengan kata lain, masyarakat yang bertindak sebagai donatur telah memiliki modal sosial yang tinggi, karena mereka mau melakukan sesuatu yang lebih dalam hubungan sosialnya yakni dengan memberikan donasi terhadap orang yang membutuhkan melalui LSPT.

Hasil wawancara dengan mustahia menunjukkan bahwa rasa percaya di antara masing-masing mustahiq belum ada atau belum terbentuk dalam program PMM. Hal ini juga ditunjukkan melalui fakta bahwa belum ada kerjasama ataupun keberanian untuk mengambil resiko dalam hubungan mereka, sebagai bentuk dari rasa percaya tersebut. Fakta lain menunjukkan bahwa program griya dakwah yang berlangsung di salah satu desa terpencil di daerah lamongan mampu membentuk rasa percaya di antara masing-masing 
Ahkamiyah, et al/Jurnal Ekonomi Syariah Teori dan Terapan Vol. 5 No.7 Juli 2018: 590-603; ANALISIS KRITIS PROGRAM PENGELOLAAN DANA ZAKAT DAN INFAK DALAM MEMBENTUK MODAL SOSIAL MASYARAKAT

jamaahnya. Menurut penuturan Ustadz yang ditugaskan di desa tersebut, warga desa yang memiliki lahan pertanian atau sawah yang cukup luas, mengikhlaskan sebagian lahannya untuk ditanami warga yang tidak memiliki lahan atau sawah. Inilah salah satu contoh modal sosial yang terbentuk di masyarakat tersebut.

Upaya LSPT dalam membentuk modal sosial terlihat dari penyaluran dana zakat dan infak yang dikemas dengan kajian rutin. Fitrah manusia bahwa manusia merupakan makhluk sosial akan membentuk kecenderungan untuk hidup berkelompok, dengan adanya kajian rutin yang diselenggarakan LSPT otomatis membuat intensitas pertemuan antar masyarakat semakin sering dan hal ini akan mampu mempererat tali silaturrahim di antara mereka serta memperkuat modal sosial. Hasil wawancara dengan beberapa informan menunjukkan bahwa sebenarnya upaya LSPT ini, bukan upaya yang ditujukan untuk membentuk modal sosial, akan tetapi tujuannya adalah berdakwah yakni membentuk membentuk masyarakat yang religius.

Kajian yang menjadi wadah bagi masyarakat untuk menambah ilmu agama dan bersilaturrahim dengan yang lain telah dijadwalkan secara baik oleh LSPT. Kajian program PMM dilakukan setiap tanggal 10 perbulannya, sedangkan untuk program griya dakwah dilakukan setiap malam jumat. LSPT juga memberikan wadah bagi seluruh elemen LSPT meliputi pengasuh, pembina, pengurus, dewan syari'ah, mustahiq serta donatur untuk saling bersilaturrahim, yaitu buka puasa bersama pada bulan Ramadhan setiap tahunnya.

Modal sosial yang mulai terbentuk ini harus dikembangkan dengan adanya silaturrahim, karena dengan adanya silaturrahim serta norma atau aturan yang dimiliki akan mendorong masyarakat untuk lebih produktif.

\section{SIMPULAN}

Berdasarkan analisis hasil dan pembahasan dalam penelitian ini, maka dapat disimpulkan bahwa Model pengelolaan dana zakat dan infak LSPT yang dapat membentuk modal sosial di masyarakat adalah program PMM dan program griya dakwah. Program PMM adalah program bantuan untuk masyarakat miskin yang dikemas dengan sistem kajian rutin setiap bulannya, dimulai dengan salat dhuha berjamaah, kajian yang diisi oleh ustadz dari Pesantren Tebuireng dan diakhiri dengan cek kesehatan gratis serta pemberian vang santunan. Program ini telah mampu membentuk modal sosial masyarakat akan tetapi belum sepenuhnya berhasil. Program griya dakwah adalah program khusus dari LSPT, yang pekerjaan utamanya adalah menerjunkan seseorang yang ahli dibidang terkait untuk berdakwah di masyarakat Ngimbang, Kabupaten Lamongan. Kegiatan utama dari program griya dakwah adalah kajian rutin setiap malam Jumat, adanya kajian 
Ahkamiyah, et al/Jurnal Ekonomi Syariah Teori dan Terapan Vol. 5 No.7 Juli 2018: 590-603;

ANALISIS KRITIS PROGRAM PENGELOLAAN DANA ZAKAT DAN INFAK DALAM MEMBENTUK MODAL SOSIAL MASYARAKAT

tersebut semakin memperkuat modal sosial di masyarakat Ngimbang.

\section{DAFTAR PUSTAKA.}

Afifuddin, dan Beni Ahmad S. 2012. Metodologi Penelitian Kualitatif. Bandung: CV. Pustaka Setia.

Al Ghaziy, Muhammad bin Qasim. 2005. Fathul Qarib Al-Mujib. Jeddah. AlHaramain.

Agustin, Atut Firda, Khusnul Ashar dan Multifiah. 2013. Identifikasi Modal Sosial pada Program Pemberdayaan Masyarakat Miskin Melalui Dana Zakat, Infak dan Sedekah. (Online) (ejournal.uinmalang.ac.id, diakses pada 12 April 2017).

Al Qurthubi, Syaikh Imam.2007. Al-Jami' Li Ahkāmi 'I-Qurăn. Vol 3. Jakarta: Pustaka Azzam.

Badan Amil Zakat Nasional. 2017. Tugas Pokok Baznas. Jakarta: BAZNAS.

Binjai, Abdul Halim Hasan. 2011. Tafsir Al Ahkam. Jakarta: Prenada Media Group.

Chaudhry, Muhammad Syarif. 2016. Prinsip Dasar Sistem Ekonomi Islam. Jakarta: Prenada Media Group

Field, John. 2010. Modal Sosial. Bantul: Kreasi Wacana.

Hafidhuddin, Didin. 2008. Panduan Praktis tentang Zakat, Infak, dan Sedekah. Jakarta: Gema Insani

Hamim, Nur Ifan. 2016. Manajemen Pengelolaan Infaq di Lembaga Sosial Pesantren Tebuireng (Tinjuan Teori Manajemen George Terry). Skripsi tidak diterbitkan. Malang Universitas Islam Negeri Maulana Malik Ibrahim Malang.

Handoyo, Eko. 2013. Kontribusi Modal Sosial dalam Meningkatkan Kesejahteraan Pedagang Kaki Lima Pascarelokasi. Jurnal Komunitas, 5 (2): 252-266

https://almanhaj.or.id (online) diakses pada 20 Juli 2017

https://tebuireng.online/yayasan-hasyimasyari/ (online) diakses pada $11 \mathrm{Juli}$ 2017

http://pusat.baznas.go.id_(Online) diakses pada 12 April 2017
Kearns, Ade. 2004. Social Capital, Regeneration \& Urban Policy. CNR Paper 15.

Mahalli, Ahmad Mudjab. 2004. Haditshadits Muttafaq 'Alaih: Bagian Ibadat. Jakarta: Prenada Media Group.

Mahalli, Ahmad Mudjab dan Ahmad Rodli Hasbullah. 2004. Hadits-hadits Muttafaq 'Alaih: Bagian Munakahat dan Mu'amalat. Jakarta: Prenada Media Group.

Mardani. 2012. Ayat-ayar dan Hadits Ekonomi Syariah. Edisi Pertama. Jakarta: Rajawali Pers

Muhammad. 201 1. Manajemen Organisasi Zakat. Malang: Madani.

Mustafa, Edwin Nasution dkk (Eds). 2009. Indonesia Zakat \& Development Report 2009. Depok: PEBS dan CID

Nasution, Ahmadriswan, Ernan Rustiadi, Bambang Juanda dan Setia Hadi. 2014. Dampak Modal Sosial terhdap Rumah Tangga Perdesaan di Indonesia. Vol.30. Mimbar, 2: 137148

Qardawi, Yusuf. 1999. Hukum Zakat. Bandung: PT Pustaka Mizan.

Quthb, Sayyid. 2000. Tafsir Fi Zhilalil Qur'an: Di Bawah Naungan Al-Qur'an. Jilid 1. Jakarta: Gema Insani.

Robison, Lindon J, Marcelo E.S and A. Allan S. 2002. Social Capital and Poverty Reduction:Toward to Mature Paradigm. Agricultural Economic Report, 614: 1-50.

Sanrego, Yulizar D dan Moch Taufik. 2016. Fiqh Tamkin (Fiqih Pemberdayaan). Jakarta: Qisthi Press

Setkab.go.id (Online) diakses 12 April 2017

Shihab, M.Quraish. 2002. Tafsir Al-Mishbah: pesan, kesan, dan keserasian AlQur’an. Vol 1. Jakarta: Lentera Hati. Q 2002. Tafsir Al-Mishbah: pesan, kesan, dan keserasian AlQur'an. Vol 3. Jakarta: Lentera Hati Q----. 2002. Tafsir Al-Mishbah: pesan, kesan, dan keserasian AlQur'an. Vol 8. Jakarta: Lentera Hati pesan, kesan, dan keserasian AlQur'an. Vol 12. Jakarta: Lentera Hati . 2002. Tafsir Al-Mishbah: pesan, kesan, dan keserasian Al- 
Qur'an. Vol 13. Jakarta: Lentera Hati.

Sugiono. 2013. Memahami Penelitian Kualitatif. Bandung: Alfabeta.

Suharto, Edi. 2008. Modal Sosial dan Kebijakan Publik.

http://www.policy.hu/suharto (Online) diakses pada 19 Juli 2017

Supono, Boedyo. 2011. Peranan Modal sosial dalam Implementasi Manajemen dan Bisnis. Vol 11. Jurnal Ekonomi dan Kewirausahaan, 1: 10-16

Syahra, Rusydi. 2003. Modal Sosial: Konsep dan Aplikasi. Vol 5. Jurnal Masyarakat dan Budaya, 1: 1-22

Syahyuti. 2008. Peran Modal Sosial (Social Capital) dalam Perdagangan Hasil Pertanian. Vol 26. Forum Penelitian Agro Ekonomi, 1: 32-43

Widayani, Retno dan Nisa Agistiani Rachman. 2013. Studi Kemunculan
Modal Sosial. Vol 17. JKAP, No 2: 175

Widiastuti, Tika. 2013. Pengaruh Kepatuhan Berzakat terhadap Kinerja BAZ dan Non-BAZ Serta Kesejahteraan Mustahiq si Jawa Timur. Disertasi tidak diterbitkan. Surabaya Pascasarjana Universitas Airlangga Surabaya.

Wahid, Salahuddin. 2011. Transformasi Pesantren Tebuireng. Malang: UIN Maliki press.

Yin, Robert K. 2003. Studi Kasus : Desain dan Metode. Jakarta: PT. Raja Grafindo Persada.

Yin, Robert K.2014.Case Study Research: Design and Methods. Fifth edition. America: SAGE

Yunus, Mahmud. 1990. Kamus ArabIndonesia. Jakarta: PT. Hidakarya Agung. 